\title{
Inflammatory cell microlocalisation and airway dysfunction: cause and effect?
}

\author{
S. Siddiqui, F. Hollins, S. Saha and C.E. Brightling
}

ABSTRACT: Airway inflammation is a critical feature of the airway diseases asthma and chronic obstructive pulmonary disease (COPD). There is emerging evidence that structural cells play a key role in the development and perpetuation of the inflammatory response and are pivotal in the development of the changes in the airway structures that lead to airway remodelling.

To date, little attention has been given to the localisation of inflammatory cells to airway structures or the potential interactions between these intimately located cells. However, it is likely that interactions between inflammatory and structural cells in the airway contribute enormously to the pathophysiology of asthma and COPD.

Indeed, recent evidence suggests that mast cells localised to the airway smooth muscle bundle may be important in the development of airway hyperresponsiveness in asthma.

In the present article, the authors aim to summarise: 1) the current understanding of which inflammatory cells locate to airway structures; 2) the proposed mechanisms that may be involved in mediating this microlocalisation; 3 ) the possible consequences of interactions between inflammatory and structural cells; and 4) the pressing need to investigate whether modulating these interactions is beneficial in asthma and chronic obstructive pulmonary disease.

KEYWORDS: Asthma remodelling, cellular interactions, chronic obstructive pulmonary disease remodelling

$\mathbf{T}$ he prevalence of obstructive airway diseases, namely asthma and chronic obstructive pulmonary disease (COPD), are increasing. Asthma affects $10 \%$ of children and $5 \%$ of adults $[1,2]$, and by 2020 it is predicted that COPD will be the third leading cause of mortality worldwide [3]. Both conditions are defined in terms of typical symptoms and abnormal airway physiology, but it is also well recognised that airway inflammation and airway remodelling are key components of both diseases [4, 5].

Asthma is characterised by airway hyperresponsiveness (AHR) and variable airflow obstruction. The airway inflammation in asthma is typically eosinophilic with increased expression of $\mathrm{T}$ helper cell (Th) type 2 cytokines [6]. Airway remodelling in asthma encompasses several structural changes in the airway wall, including reticular lamina and basement membrane thickening, an increased number of subepithelial myofibroblasts and increased airway smooth muscle (ASM) mass [7, 8].

The hallmark of COPD is irreversible airflow obstruction. Pathologically, COPD consists of a combination of emphysema and obliteration of the small airways. These two pathologies are distinct, in that emphysema can occur without narrowing of the small airways and vice versa, although the conditions usually coexist [9]. Small airway narrowing results as a consequence of mucus hypersecretion, inflammation and remodelling due to fibrosis, and increased ASM mass [4]. The inflammatory infiltration in the airway in COPD comprises of T-cells with a relative preponderance of CD8+ cells, macrophages and neutrophils $[4,10]$.

Although the features of the disordered airway physiology, inflammatory profile and structural changes in the airway in asthma and COPD are well described, the interactions between these components of airway disease are poorly understood. To date, little attention has been paid to the localisation of inflammatory cells within structural compartments of the airway wall. Recently, enthusiasm for the view that microlocalisation is important in obstructive airway diseases has been fuelled by studies showing inflammatory cells within the ASM in asthma [11-18] and

\section{AFFILIATIONS}

Institute for Lung Health, Dept of Infection, Inflammation and Immunity, University of Leicester, Leicester, UK.

CORRESPONDENCE

C.E. Brightling

Dept of Respiratory Medicine University Hospitals of Leicester Groby Road Leicester LE3 9QP UK Fax: 441162502787 E-mail: ceb17@le.ac.uk

Received:

December 122006 Accepted after revision: July 302007

STATEMENT OF INTEREST None declared.

European Respiratory Journal Print ISSN 0903-1936 Online ISSN 1399-3003 
COPD [19], but not in normal controls. Most notably, in asthma the ASM is infiltrated by mast cells and the number of mast cells within the ASM bundle was associated with the degree of AHR [11].

Communication between cells within the airway predominately occurs across distances of only a few microns, as many inflammatory mediators are rapidly inactivated once they leave the cell. Thus, direct cell-cell interactions are likely to be critical in modulating cellular function. It is therefore likely that microlocalisation between inflammatory and structural cells is a fundamental organising principle of airway inflammation and repair.

The present study will: review the evidence that inflammatory cells localise to structural cells focused particularly on mast cell localisation to the ASM bundle; review the functional consequences of interactions between these cells; review the mechanisms driving this co-location; consider how these interactions may be further studied; and speculate on the therapeutic potential of modifying these interactions.

\section{INFLAMMATORY CELL MICROLOCALISATION TO STRUCTURAL COMPONENTS WITHIN THE AIRWAY}

Most immunopathological descriptions of asthma and COPD have focused on the number of inflammatory cells that infiltrate the airway submucosa. Often, structural components of the airway are excluded. There is an increasing recognition that inflammatory cells selectively localise to different airway structures in disease (as summarised in table 1) and it is biologically plausible that this microlocalisation has important functional consequences. For example, bronchoconstriction is a consequence of ASM contraction. Therefore, the localisation of inflammatory cells within the ASM bundle is likely to modulate AHR and variable airflow obstruction.

The recognition of the importance of microlocalisation is not confined to inflammatory cells and ASM cells but is equally critical in interactions with other structural cells, such as the epithelium, fibroblasts, mucosal glands and nerve cells.

\section{Inflammatory cell localisation to ASM bundle}

In asthma and, according to some reports, in nonasthmatic subjects, the ASM bundle is infiltrated by mast cells, predominately of the chymase-positive phenotype [11-18]. Mast cell-ASM interactions in asthma are summarised in figure 1. Mast cells adhere avidly to ASM, in part via a tumour suppressor in lung cancer-1 heterophilic adhesion molecule and in part via an unidentified $\mathrm{Ca}^{2+}$ independent pathway [47]. Mast cell number correlated positively with the degree of AHR [11] and with the bronchoconstrictor response to a deep inspiration [44], suggesting that mast cell-ASM cell interactions are likely to be central in the development of the disordered physiology in asthma. The strength of this assertion was underpinned by the paucity of mast cells within the ASM bundle in eosinophilic bronchitis, a condition that presents with chronic cough and shares many of the immunopatholgical features of asthma but is not associated with airflow obstruction or AHR [11, 25, 48-50]. Although most studies have reported an increase in the number of mast cells in the ASM bundle in asthma, some have not been able to confirm this observation [42]. However, although BALZAR et al. [51] did not report a significant increase in the number of mast cells in the ASM bundle in asthma, the numbers were double that observed in normal controls and this almost reached statistical significance $(p=0.06)$. Importantly, there is evidence that mast cells infiltrating the ASM bundle are activated with increased expression of Th2 cytokines interleukin (IL)-4 and IL-13 [43]. A post mortem study of fatal and nonfatal asthma has shown that there was a marked increase in mast cell degranulation in the ASM bundle in both the large and small airways [12]. Another study demonstrated that increased numbers of mast cells (degranulated and intact) are associated with increased ASM shortening in fatal asthma [37]. Interestingly, there was a paucity of other inflammatory cells, with only one study reporting the presence of T-cells in the ASM bundle [18], suggesting that it is predominantly mast cells that are selectively recruited to the ASM bundle.

Inflammatory cell localisation to the ASM bundle is also a phenomenon of COPD. BARALDO et al. [19] found increased numbers of neutrophils and CD8+ cells, but not mast cells, in the small airways of smokers with COPD, and noted that the neutrophil number was inversely related to lung function. This is consistent with an earlier study showing that the number of neutrophils in the ASM bundle in small airways in smokers is related to air trapping determined by computed tomography scanning [45]. In the latter report, there was also a relationship between air trapping, reflecting peripheral obstruction and infiltration of ASM by chymase-positive mast cells. This result indicates that mast cells may also play a role in COPD, at least at the peripheral level. This picture is not replicated in the large airway in COPD as, although T-cells, macrophages and mast cells were present in the ASM bundle, the number of inflammatory cells in the ASM bundle was not different between subjects with COPD (Global Initiative for Obstructive Lung Disease (GOLD) I-II) and non-COPD smoking and nonsmoking controls [39, 42, 46]. However, in contrast to studies in asthma, macrophages, neutrophils and T-cells were observed in the ASM bundle in low numbers in resection specimens from subjects with and without COPD. Most of the subjects in these studies were older and had undergone lung resection for cancer; thus, although the airways studied were considered to be from unaffected areas, there remains the possibility of the underlying lung cancer contributing to the inflammatory changes described. Nevertheless, the body of evidence strongly suggests that microlocalisation of inflammatory cells within the ASM bundle is an important feature in the small airway in COPD and in both the large and small airway in asthma.

Activation of the inflammatory cells within the ASM bundle would be predicted to have important consequences on ASM function. Following mast cell degranulation, the mediators histamine, prostaglandin $(\mathrm{PG}) \mathrm{D}_{2}$ and leukotriene $(\mathrm{LT}) \mathrm{C}_{4}$ are released, which are all potent agonists for ASM contraction [52]. Mast cell cytokines may further contribute to AHR. The mast cells in the ASM bundles in asthma, but not in COPD, express IL-13 [53]. IL-13 has been shown to attenuate relaxation to $\beta$-agonists and augment contractility to acetylcholine [54, 55]. Similarly, the mast cell protease may be important in modulating ASM contractility and AHR [56]. The effect of neutrophil-derived mediators on ASM function is less clear, with conflicting reports from animal studies showing that 
TABLE 1 Inflammatory cell localisation to airway structures

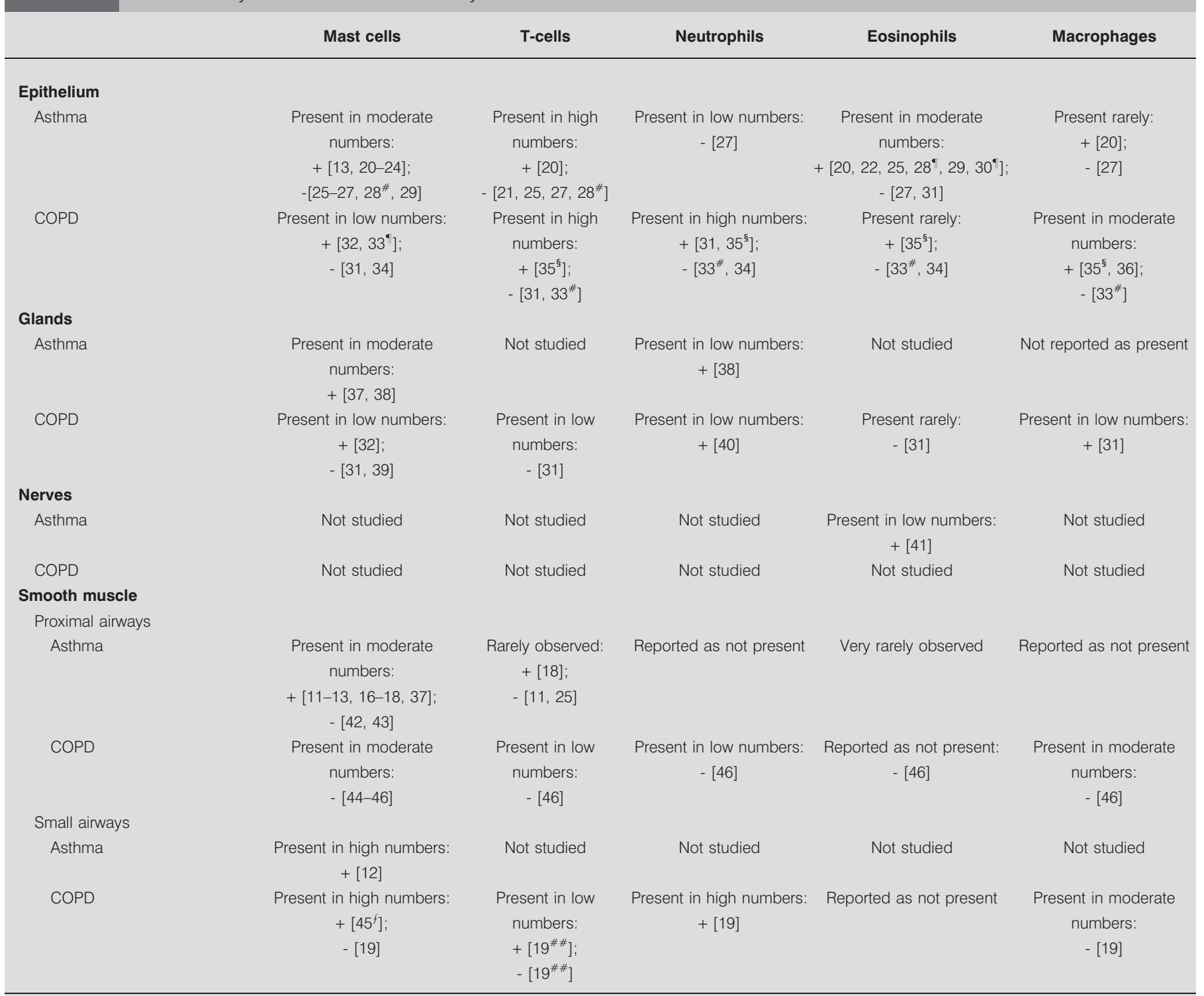

COPD: chronic obstructive pulmonary disease. +t: present and increased compared with control; -: present but not increased compared with control. ${ }^{\#}$ : inhaled corticosteroids did not significantly reduce intra-epithelial cell numbers compared with placebo; ${ }^{\prime}$ : inhaled/oral corticosteroids reduced intra-epithelial cell count compared with placebo; ${ }^{\text {s: }}$ epithelium and submucosa used as denominator for cell counts; ${ }^{f}$ : smokers with and without spirometric evidence of COPD; ${ }^{\# \#}$ : increased CD8+ cells, CD4+ cells not increased.

elastase can increase and diminish smooth muscle responsiveness $[57,58]$.

The interactions between inflammatory cells and ASM cells may have more long-term consequences. Mast cells cocultured with ASM promote ASM differentiation with increased $\alpha$-smooth muscle actin expression [59]. Similarly, mast cell differentiation towards the chymase-positive phenotype observed within the ASM bundle may be mediated by mast cell-ASM interactions. Increased ASM mass is a wellestablished feature of both asthma [60] and COPD [10]. A number of mast cell mediators, including histamine [61], tryptase [62] and $\mathrm{LTD}_{4}$ [63], as well as the neutrophil product elastase [64], promote ASM proliferation. Alternatively, increased ASM mass may be a consequence of recruitment of ASM progenitors. This view is supported by the increased number of fibrocytes that migrate into the airway following allergen challenge [65]. Recent evidence suggests that ASM migration towards the ASM bundle is mediated by activation of CC chemokine receptor (CCR)7, ASM- and mast cell-derived CC chemokine ligand (CCL)19 [26]. In asthma, increased ASM mass occurs predominantly in the large airway and in COPD in the small airways. Small ASM mass is inversely associated with post-bronchodilator forced expiratory volume in one second in COPD [10]. Using a computational model, increased muscle mass has been shown to be probably the most 


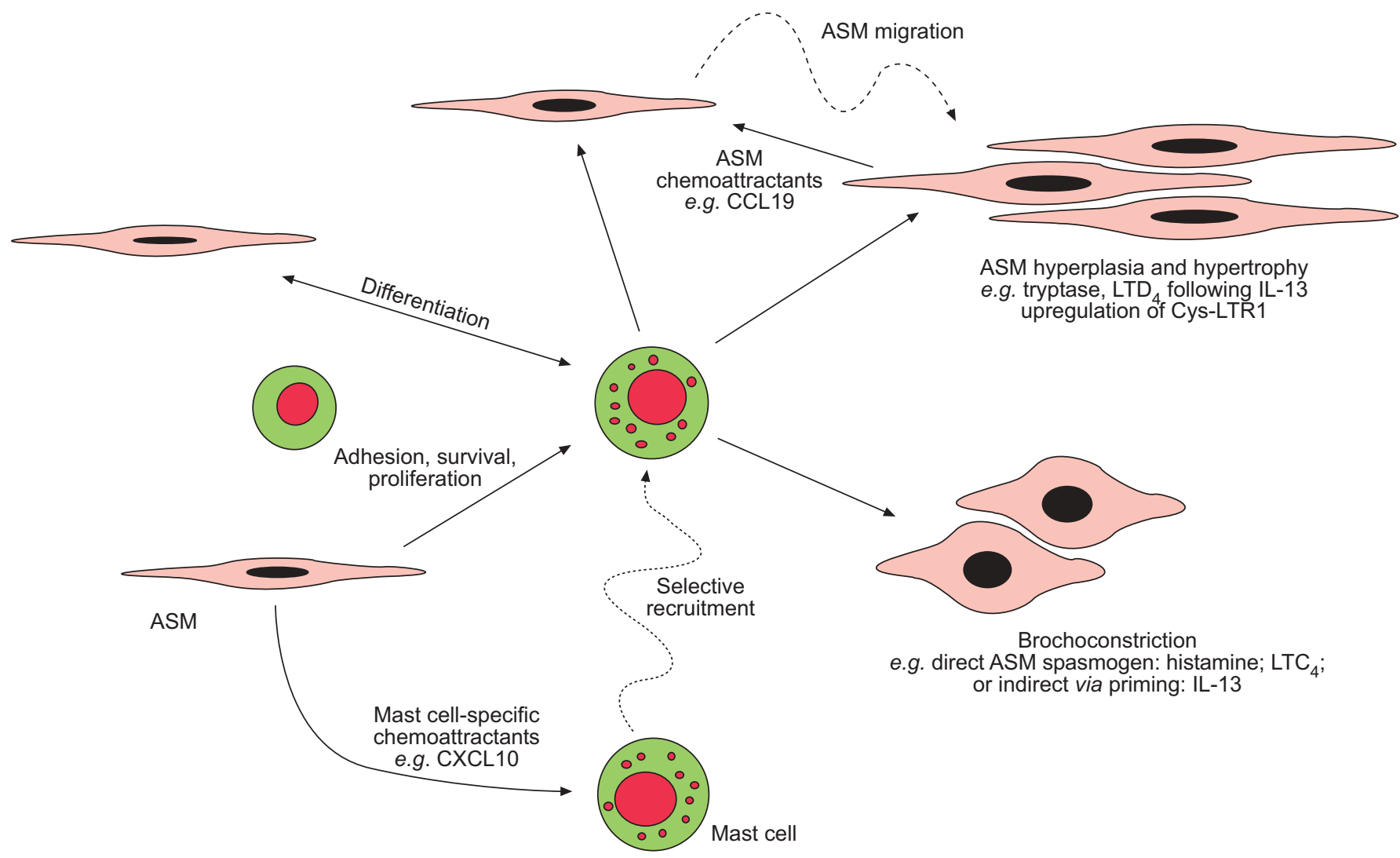

FIGURE 1. Mast cells are recruited to the airway smooth muscle (ASM) under the influence of ASM-derived chemoattractants and avidly adhere to ASM. In the ASM bundle there is an appropriate milieu to support mast cell survival and the cells interact resulting in cellular differentiation, ASM hyperplasia, recruitment of ASM progenitors and ASM contraction either directly or indirectly. CCL: CC chemokine ligand; CXCL: CXC chemokine ligand; LT: leukotriene; IL: interleukin.

important abnormality responsible for the increased airflow resistance observed in response to bronchoconstricting stimuli in both asthma and COPD [66]. Consistent with this view, in a cross-sectional study of the immunopathology of asthma across severity using a multiple regression model, increased ASM mass and ASM hypertrophy were the features of remodelling that were associated most strongly with impairment in lung function [7]. The relative contribution of ASM mass to overall airway wall thickness in the small airways is much greater than that in the large airways. Thus, increased ASM mass in the small airways is likely to make a significant contribution to the development of fixed airflow obstruction characteristic of COPD and sometimes seen in persistent chronic severe asthma.

Therefore, mast cell interactions with ASM in asthma are likely to be important in the development of AHR and may play a critical role in the development of increased ASM mass and the development of fixed airflow obstruction seen in severe disease. The role of inflammatory cell-ASM interactions in COPD in the small airway may be related to gas trapping, but in the large airway the role of ASM-inflammatory cell interactions is uncertain and needs to be further explored.

\section{Inflammatory cell localisation to (myo)fibroblasts}

In asthma, interactions between the airway epithelium and mesenchymal cells, known as the epithelial-mesenchymal trophic unit, are well described [67, 68]. There are increased numbers of subepithelial myofibroblasts in asthma, which are correlated with the degree of reticular basement membrane thickening [69]. This layer of mesenchymal cells is in close proximity to the epithelium and the activation of the airway epithelium, secondary to epithelial damage, is likely to be critical in regulating the activation of the airway mesenchyme. Whether inflammatory cells are co-localised to subepithelial mesenchymal cells is unclear. However, there is evidence that implicates mast cells, eosinophils and T-cells in playing a key role in perpetuating interactions between epithelial and mesenchymal cells. For example, in co-culture with mast cells, primary bronchial fibroblasts from asthmatics increase their expression of pro-collagen 1 expression mediated by mast cellderived IL-4 [70]. Cytokines IL-4 and IL-13 activate epithelial cells in vitro to produce transforming growth factor (TGF)- $\beta 2$, as well as having a direct effect upon myofibroblasts promoting CCL11 release and eosinophil recruitment to the subepithelium [71]. Submucosal mast cells, eosinophils [43, 72] and T-cells [73] are important sources of these cytokines.

In COPD, subepithelial fibrosis is an important component of small airway obliteration. However, the importance of inflammatory cells localised and interacting with mesenchymal cells in this disease is unclear.

\section{Inflammatory cell localisation to mucus glands}

Mucus production is a cardinal feature of asthma and COPD and mucus gland hyperplasia is a feature of both conditions 
$[39,74-76]$. Patients with asthma across the spectrum of severity, including fatal asthma, demonstrate increased numbers of degranulated mast cells [12,37] and neutrophils [38] within submucosal glands compared with controls. However, the degree of mucus-related obstruction expressed as the percentage of the airway lumen occupied by mucus only correlated with mast cell numbers and not with neutrophil numbers [38]. In COPD, the submucosal glands are infiltrated by neutrophils and macrophages [31]. Whether mast cells infiltrate the mucus glands in COPD is controversial, with two reports supporting [32, 39] and another refuting [31] the location of mast cells in glands. Eosinophils and T-cells were not increased in number in submucosal glands in asthma or COPD. A recent report has demonstrated that plasma cells are increased in the submucosal glands in patients with COPD and chronic bronchitis without airflow limitation, compared with smoking controls [39]. Furthermore, there was a close correlation between the number of plasma cells in glands and the number of IL-4 mRNA cells and protein expressing cells within the glands, and an increase in mucus in the glandular epithelium compared with smoking controls. Mast cells were present but not increased in glands and the ASM in COPD, chronic bronchitis and smoking controls in the study [39].

Mast cell proteases, tryptase and chymase are potent stimuli for mucus secretion and other mast cell mediators, $\mathrm{PGD}_{2}$ and $\mathrm{LTC}_{4}$ [40], together with mast cell-derived cytokines, IL-6, IL13 [77] and IL-4 [78], have also been implicated in glandular hyperplasia and mucus production. More recently, mast cell expression of amphiregullin, a member of the epidermal growth factor family, was increased in asthma and this upregulates mucin gene expression by epithelial cells, implicating amphiregullin in goblet cell metaplasia and mucus hypersecretion [79, 80]. Similarly, neutrophils may promote mucus hypersecretion by upregulation of MUC5AC by neutrophil elastase [81, 82].

\section{Inflammatory cell localisation to airway epithelium}

A variety of inflammatory cells infiltrate the airway epithelium. This is likely to be important, as it places these cells at the mucosal interface with pathogenic and allergic stimuli promoting an effector role for inflammatory cells in the ongoing immune response and facilitating cellular interactions. In asthma and healthy subjects, T-cells are the most abundant inflammatory cell in the epithelium [20, 25, 27, 28] but increased numbers of T-cells in the epithelium in disease is rarely reported [20], and most studies do not support the view that T-cells are selectively recruited to the epithelium [21, 27]. Similarly, in COPD, both granulocytes and T-cell numbers have been shown to be increased in the epithelium in some studies [31, 35] but not in all [31, 33, 34]. In contrast, eosinophils and dendritic cells are consistently reported to be increased in the epithelium in asthma $[20,22,25,29,30]$. In most reports [13, 20-24, 32, 33], but not all [25, 27-29, 31, 37], mast cell numbers are increased in the airway epithelium in asthma and COPD. In addition, neutrophil infiltration into the airway epithelium is a feature of COPD [27].

Mast cells adhere avidly to airway epithelium via a carbohydrate-dependent mechanism [83] and mast cell survival is promoted by epithelial cell-derived stem cell factor [84]. Mast cells activate epithelial cells through release of IL-4, IL-13 and tryptase $[43,85]$, but in contrast epithelial cells attenuate both constitutive and immunoglobulin (Ig)E-dependent histamine release from human lung mast cells [86].

Eosinophils adhere to epithelial cells via a CD18-dependent mechanism closely regulated by the local cytokine milieu [87, 88 ], and survival is maintained, in part, by release of nerve growth factor and brain-derived growth factor. Adhesion leads to eosinophil activation, release of eosinophil cationic protein [89] and promotes epithelial apoptosis [90]. T-cells also promote epithelial apoptosis [90], activation via release of cytokines and, reciprocally, epithelial cells augment T-cell proliferation and activation [91]. The increase in epithelial apoptosis may contribute to the increased epithelial fragility and shedding often described in asthma [8], although whether this is a real feature of asthma or a biopsy artefact remains unclear [92, 93].

Survival of dendritic cells in the airway epithelium is maintained in part by granulocyte-macrophage colony-stimulating factor (GM-CSF) released by the epithelium in response to protease-activated receptor-2 activation [94]. Retention is augmented by enhanced epithelial intercellular adhesion molecule- 1 expression and activation with Th2 polarisation by release of a variety of mediators, in particular $\mathrm{PGE}_{2}$ and IL$10[95,96]$. Reciprocally, the expression of CD40L by dendritic cells enhances production of chemokines, pro-inflammatory cytokines and epithelial defensins by the asthmatic epithelium, and represents an important arm of the innate epithelial immune response [97].

\section{Inflammatory cell localisation to airway nerves}

To date, interest has focused on eosinophil-airway nerve interactions. Eosinophils have been shown to cluster around cholinergic nerves in patients with fatal asthma [41]. There are no reports in human disease that describe the presence or absence of other inflammatory cells co-localised to airway nerves, but a guinea pig model of asthma suggests that there may be selective localisation of esoinophils to airway nerves as there was a paucity of other inflammatory cells.

The dominant nervous innervation of the airways is vagally mediated via the parasympathetic nervous system [98]. Release of acetylcholine from these nerves has a variety of consequences regulated by local muscarinic receptors, including bronchoconstriction [98], release of mucus from glands [99] and vasodilatation [100]. Cholinergic-mediated AHR seems to be related to loss of muscarinic 2 receptor (M2R) inhibition rather than increased expression/altered function of M3R on ASM [101, 102]. The interaction of eosinophils with M2Rs is important to the pathogenesis of neuronal AHR. Eosinophils co-cultured with human Caucasian neruoblastoma cell line cell leads to increased expression of the M2R, which is mediated via an adhesion-dependent release of eosinophil proteins, including major basic protein and nerve growth factor, increasing acetylcholine release and potentiating vagally mediated bronchoconstriction [103].

Eosinophilic bronchitis, cough, variant asthma and idiopathic chronic cough are associated with increased concentration of mast cell products in sputum [104, 105]. Therefore, it is possible, but as yet unproven, that localisation of mast cells to sensory nerve endings might be important in the 
development of cough reflex hypersensitivity and cough. A rather similar interaction is thought to be important in the genesis of itch [106, 107]. In COPD, the potential role of airway nerve-inflammatory cell interactions has not been investigated.

\section{Inflammatory cell localisation to vasculature}

Vascular remodelling occurs in asthma and COPD [108-111] and is associated with airflow obstruction [108]. The role of vascular remodelling in the development of AHR in asthma is contentious. KANAZAWA et al. [112] demonstrated that vascular epidermal growth factor (VEGF) was increased in the sputum in asthma, but not in nonasthmatic eosinophilic bronchitis, and correlated with increased airway vascular permeability and AHR. However, the duration of disease in the nonasthmatic eosinophilic bronchitis cohort in the study by KANAZAWA et al. [112] is unclear and disease duration is critical in assessing the impact of some features of airway remodelling [113]. The current authors have recently demonstrated in patients with chronic nonasthmatic eosinophilic bronchitis that vascular remodelling does occur to a similar degree as in moderate-tosevere persistent asthma and is, therefore, unlikely to be related to AHR [114]. The increased vascularity in asthma was related to disease duration and airflow obstruction, but not AHR.

Very few studies have examined the association of cellular interactions and vascular remodelling in asthma and COPD. CHETTA et al. [111] demonstrated that the number of mast cells in the subepithelium correlates with the number of vessels in asthma; however, a similar correlation was not observed for eosinophilic airway inflammation. Although studies have described an association with sputum VEGF and percentage of eosinophilia in sputum [115], a similar relationship in vivo has not been described. Despite the lack of data linking airway inflammation and vascular remodelling in asthma, growth factors (VEGF, $\beta$-fibroblast growth factor and angiogenin) colocalise predominantly to eosinophils, macrophages and CD34+ cells in vivo, and the expression of these growth factors correlates with the percentage of vascularity of the airway wall [116]. Furthermore, the expression of the main signalling receptor for VEGF (FLT-1) is increased in vessels in asthmatics [109]. Taken together, these observations suggest that eosinophils, macrophages and mesenchymal cells may be important in regulating vascular remodelling in asthma. However, it remains unclear whether inflammatory cells are selectively colocalised to vessels in asthma or COPD.

\section{IS THE PATTERN OF LOCALISATION OF INFLAMMATORY CELLS TO AIRWAY STRUCTURES CONSISTENT BETWEEN SMALL AND LARGE AIRWAYS?}

Although a large number of studies have examined cellular localisation to the airway wall in large and small airways, few have assessed the distribution of inflammatory cells to specific structures within the airway wall according to airway size.

Mast cell smooth muscle mysotitis has been consistently observed in proximal ASM and has also been reported in small airway wall smooth muscle in asthma [11, 12, 13, 16-18, 37]. Although mast cell density was increased in membranous compared with cartilaginous airway in the epithelium and ASM in one study [12], mast cell numbers were not increased in COPD compared with controls in the proximal airway smooth muscle $[39,46]$ and conflicting data exist for the distal airways. One study showed increased mast cells in the ASM [45] and another reported that numbers were not increased compared with healthy controls [19]. Similarly, T-cells, neutrophils and macrophages (but not eosinophils) have been observed in the ASM in large and small airways in COPD, but only small airway CD8+ T-cells and neutrophils have been shown to be increased compared with healthy controls [19, 46].

Further studies are required to establish whether the localisation of inflammatory cells to airway structures is consistent between large and small airways in asthma and COPD.

\section{WHAT MECHANISMS ARE INVOLVED IN SELECTIVE LOCALISATION?}

Inflammatory cells microlocalise to specific compartments within the airway, with an abundance of some and a paucity of other cells within airway structures. Inflammatory cell localisation is a feature of asthma and COPD, but interestingly the pattern of this microlocalisaion is different. This raises the question: what are the mechanisms controlling the selective recruitment of inflammatory cells to structural compartments within the airway?

Granulocyte trafficking has been extensively studied and characterised [117]. For example, the recruitment of eosinophils into the airway is mediated by a multi-step process directed by Th cytokines. The first step is increased production and release of eosinophils from the bone marrow under the influence of IL-5 [118, 119] and specific chemoattractants, such as CCL11 (eotaxin) [120], CCL5 (RANTES) [121], CCL12 (monocyte chemotactic protein-5) [121] and CCL3 (macrophage inhibitory protein-1 $\alpha$ ) [121]. Secondary target organ vasculature has increased adhesiveness for eosinophils through the specific effects of locally generated IL-4 and IL13. These cytokines induce the expression of vascular cell adhesion molecule (VCAM)-1 that binds to eosinophils through the very late activation antigen-4 receptor, which is not expressed by neutrophils, and P-selectin, to which eosinophils bind with greater avidity than neutrophils [122124]. The interaction of the eosinophil with these adhesion molecules is mediated by integrins $\left(\alpha_{4} \beta_{1}\right.$ and $\left.\alpha_{4} \beta_{7}\right)[125,126]$, which have been shown to bind to VCAM-1 [127]. Following adhesion, transmigration across the endothelium is mediated by complement proteins such as C5a [128]. The final phase of trafficking involves chemotaxis, which is mediated by chemokines, such as CCL11 [129], and involves encryption and passage through the matrix network of the airway wall. CCL11 has been shown to bind to CCR3, a high-affinity receptor expressed by eosinophils, and mediates directional migration through tissue [130]. Survival of eosinophils is augmented by IL-5 [131] and GM-CSF [132]. In contrast, the mechanisms involved in the recruitment of inflammatory cells in tissue to structural components is poorly understood.

Selective recruitment of inflammatory cells to the ASM is likely to be mediated by smooth muscle-derived chemoattractants and by the maintenance of the correct microenvironment to maintain cell differentiation and survival. ASM has a significant secretory capacity, so it clearly has the potential to recruit inflammatory cells [133]. For example, CXC chemokine ligand (CXCL)8 (IL-8) and CXCL10 (interferon-inducible 
protein-10) released by activated ASM in COPD may mediate neutrophil and CD8+ cell migration into the ASM bundle in the small airway [134, 135]. A plethora of chemotactic factors for mast cells are released by ASM, notably stem cell factor [16], CCL11 (eotaxin) [136-138], CXCL8 (IL-8) [136, 139], CX3C chemokine receptor 1 [17] and TGF- $\beta$ [16]. CXC chemokine receptor $(\mathrm{CXCR}) 3$ is the most abundantly expressed chemokine receptor on human lung mast cells within the ASM bundle. Human lung mast cell migration is induced by the CXCR3 ligand CXCL10, which is released preferentially from Th1stimulated asthmatic ASM cells compared with those from healthy controls [140] and is released in response to Toll-like receptor-3 activation [141]. Interestingly, Th2-stimulated ASM from asthmatics is chemotactic for mast cells compared with nonasthmatic ASM mediated via activation of CCR3 and CXCR1. This is not due to differential expression of chemokines but is likely to be due to the release of a factor that inhibits mast cell migration released by the nonasthmatic ASM [138]. It is also important to consider why some inflammatory cells, notably eosinophils and T-cells, are rarely seen in the ASM in spite of appropriate chemotactic signals. Eosinophil paucity in ASM may be explained by selective cleavage of eosinophil chemoattractants CCL5 (RANTES) and CCL11 (eotaxin) by mast cell $\beta$-tryptase [142]. Similar interactions may explain the lack of other cells, such as T-lymphocytes from ASM bundles, in asthma as LAZAAR et al. [143] demonstrated that mast cell chymase inhibited integrin-mediated T-cell adhesion to ASM cells.

Similarly, the airway epithelium has the capacity to secrete a number of chemokines that are involved in the recruitment of inflammatory cells [144, 145]. The induced sputum CXCL10 concentration from subjects with nonasthmatic eosinophilic bronchitis is increased and mediates mast cell migration via CXCR3 activation [146]. Airway epithelium is an important source of CCR3 ligands, which play a role in the recruitment of mast cells, eosinophils and Th2 cells. CXCL8 is an important neutrophil and mast cell chemoattractant, and its expression is increased in induced sputum from subjects with COPD [147, 148] and neutrophilic asthma [149], and is increased in response to cigarette smoke [150]. How chemokines interact to recruit inflammatory cells to the airway epithelium is poorly understood and it is unknown why there is less selection in cell recruitment than observed in the ASM.

Chemokine expression by airway mucus glands has not been extensively examined. CXCL8 mRNA expression by mucus glands is increased in response to Pseudomonas infection in bronchiectasis [151]. However, to date, there are no data to explain the selective recruitment of mast cells and neutrophils to the airway mucus glands in asthma, and neutrophils and macrophages in COPD. The mechanisms described to date involved in the selective microlocalisation of mast cells to ASM, epithelium and mucosal glands in asthma are summarised in figure 2 .

Eosinophil localisation to airway nerves is mediated by the release of CCR3 ligands by nerves [152]. It would be predicted that airway nerve-derived CCL11 would also recruit Th2 cells and mast cells, but whether eosinophil localisation to the airway nerves in human disease is selective is unclear.
It is likely that a number of chemokines, other chemotaxins and inhibitory factors play a role in the selective recruitment of inflammatory cells into the airway. As previously described, it may be that the release of chemotaxins by ASM and other airway structural cells varies in response to different stimuli, such as cigarette smoke, infection or allergen exposure. Future studies should explore the relative importance of these triggers and the associated network of chemotaxins that are released in promoting selective inflammatory cell microlocalisation to structural compartments of the airway.

\section{HOW CAN INFLAMMATORY CELL MICROLOCALISATION AND ITS CONSEQUENCES BE MEASURED OR MODELLED?}

Animal models have provided insight into the mechanisms that underlie inflammatory cell migration into the airway. There has been little focus on the localisation of cells to structural components of the airway and currently there is no established animal model to study mast cell localisation to the ASM bundle. Indeed, on the contrary, in a rat model of asthma CD4+ cells were located within the ASM bundle and were implicated in driving ASM proliferation [153]. However, whether T-cell localisation to the ASM bundle is a feature of asthma is contentious, with one report supporting this view but most unable to identify T-cells in the ASM bundle. Therefore, the relevance of current animal models to human disease is questionable.

In vitro two-dimensional migration assays have been informative about inflammatory cell migration towards primary structural cells from asthmatics [140], but further work studying cell migration in three-dimensional culture systems and in ex vivo bronchial biopsies using advanced imaging, for example two-photon microscopy [154], may improve current understanding of inflammatory cell migration in more biologically relevant models.

Whether inflammatory cell-structural cell interactions drive airway remodelling is unclear. However, advances in designbased stereological methods in the assessment of bronchial biopsies [155-158] and improvements in imaging techniques [159-162] have provided new objective tools with reduced bias to assess airway remodelling. These approaches will assist in defining the interplay between inflammatory cell localisation to the airway structures, disordered airway physiology and remodelling in obstructive airways disease. It is important that future studies not only use these techniques in cross-sectional studies but are used to study airway remodelling longitudinally and the effects of pharmacological and nonpharmacological interventions.

\section{CAN LOCALISATION BE MODULATED: IS THERE EVIDENCE TO SUGGEST THIS MAY BE HELPFUL?}

There are relatively few studies that have examined the inflammatory cell composition of bronchial biopsies in response to anti-inflammatory therapies in asthma and COPD [28, 30, 33, 163-171]. To date, none of these have examined the effect of treatment on cellular infiltration into the ASM bundle, mucus gland or localisation to airway nerves. Therefore, it is unknown whether recruitment of inflammatory cells into these compartments is steroid responsive, or indeed 

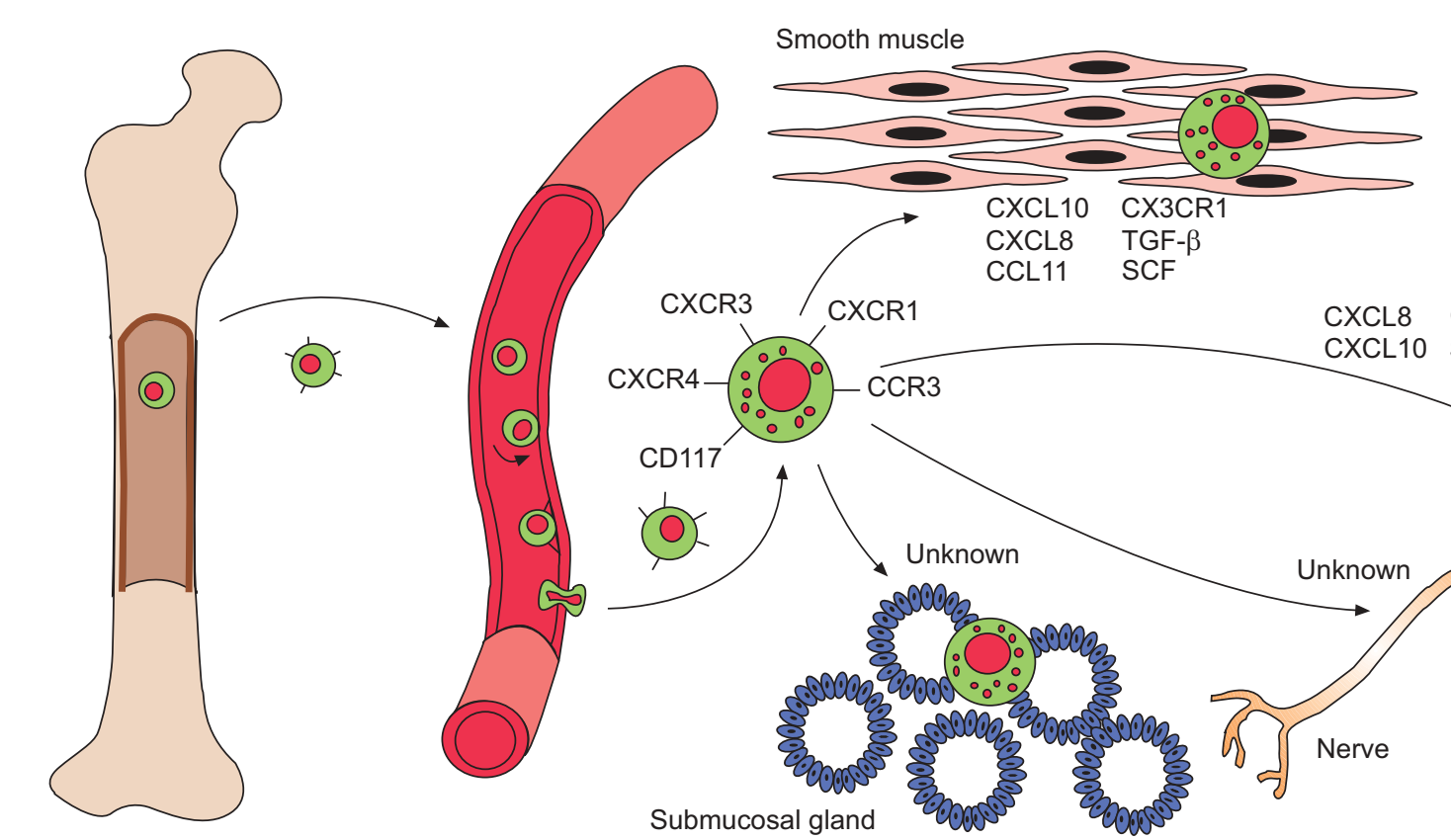

Epithelium

FIGURE 2. Schematic diagram showing mast cell trafficking to airway structures. In the airway, mast cells traffic to airway structures, namely the airway smooth muscle bundle, epithelium and mucus glands. The mechanisms known to be involved in this microlocalisation are as shown. CCL: CC chemokine ligand; CXCL: CXC chemokine ligand; CXCR: CXC chemokine receptor; TGF: transforming growth factor; SCF: stem cell factor.

responsive to any current therapy, or whether it is refractory to anti-inflammatory therapy.

In asthma, oral and inhaled corticosteroids consistently reduce the number of eosinophils in the airway epithelium [28, 30] and some, but not all, report reductions in T-cells and mast cells [28]. A limited number of bronchoscopy studies that have examined the anti-inflammatory effect of corticosteroids in COPD have not identified a consistent anti-inflammatory effect $[33,163,164]$. For other anti-inflammatory therapy the picture is also unclear and the data sparse. There are no reports on the effects of anti-LT therapy on cellular localisation to airway structures; anti-IgE in asthma led to a reduction in T-cells in the airway epithelium [172] but there was no change in other cell numbers and the phosphodiersterase- 4 inhibitor cilomilast had no effect on neutrophil numbers in the epithelium in COPD [173]. There is therefore a pressing need to understand the effect of current treatment on modulating inflammatory cell localisation to structural cells.

Recruitment of inflammatory cells into the airway is an important target for treatment of asthma and COPD. In addition to treatments with broad anti-inflammatory actions, a number of antibody and small-molecule therapies have been developed, or are in development, to target specific aspects of cell trafficking [174]. For example, anti-IL-5 reduces the number of eosinophils in the airway [175] but whether this has an impact on eosinophil infiltration into the epithelium is unknown and, more importantly, whether anti-IL-5 has clinical benefits, e.g. in reducing asthma exacerbations, is uncertain. In animal models of asthma, CCR3 antagonists reduce the clustering of eosinophils along cholinergic nerves and AHR secondary to M2R dysfunction [152]. In COPD, strategies to block CXCR2 and CXCR3 are in development and may offer novel approaches to reducing the inflammatory profile in COPD, which is currently not affected by pharmacotherapy. The potential efficacy of such an approach is supported by a recent safety study that used a monoclonal antibody to IL-8 in COPD, which resulted in small improvements in dyspnoea score [176]. Alternative strategies that target events in cellular activation involved in migration may offer novel therapies. For example, the mast cell calcium-activated potassium channel modulates the retraction of the cell body during migration. Specific inhibition of this ion channel by TRAM-34 attenuated CXCL10-mediated mast cell migration [177].

Whether inflammatory cell localisation to structural cells can be modulated by current and future treatments needs to be examined further and the functional consequences of this inhibition need to be fully determined.

\section{CONCLUSION}

Emerging evidence suggests that inflammatory cell microlocalisation to structural cells has important functional consequences. Understanding the fundamental steps that are involved in the migration of inflammatory cells towards structural cells, such as the airway smooth muscle bundle and the interactions between these cells, may provide novel targets for the future treatment of asthma and chronic obstructive pulmonary disease. Therefore, researchers interested in the immunopathology of airway diseases need to be mindful of the importance of inflammatory cell localisation and consider how this may be modulated in the future. 


\section{REFERENCES}

1 Pearce N, Douwes J. The global epidemiology of asthma in children. Int J Tuberc Lung Dis 2006; 10: 125-132.

2 Lugogo NL, Kraft M. Epidemiology of asthma. Clin Chest Med 2006; 27: 1-15, v.

3 Lopez AD, Mathers CD, Ezzati M, Jamison DT, Murray CJ. Global and regional burden of disease and risk factors, 2001: systematic analysis of population health data. Lancet 2006; 367: 1747-1757.

4 Hogg JC, Chu F, Utokaparch S, et al. The nature of smallairway obstruction in chronic obstructive pulmonary disease. N Engl J Med 2004; 350: 2645-2653.

5 Wardlaw AJ, Brightling CE, Green R, Woltmann G, Bradding P, Pavord ID. New insights into the relationship between airway inflammation and asthma. Clin Sci (Lond) 2002; 103: 201-211.

6 Brightling CE, Symon FA, Birring SS, Bradding P, Pavord ID, Wardlaw AJ. TH2 cytokine expression in bronchoalveolar lavage fluid $\mathrm{T}$ lymphocytes and bronchial submucosa is a feature of asthma and eosinophilic bronchitis. J Allergy Clin Immunol 2002; 110: 899-905.

7 Benayoun L, Druilhe A, Dombret MC, Aubier M, Pretolani M. Airway structural alterations selectively associated with severe asthma. Am J Respir Crit Care Med 2003; 167: 1360-1368.

8 Jeffery PK. Remodeling in asthma and chronic obstructive lung disease. Am J Respir Crit Care Med 2001; 164: S28-S38.

9 Hogg JC. Pathophysiology of airflow limitation in chronic obstructive pulmonary disease. Lancet 2004; 364: 709-721.

10 Saetta M, Di Stefano A, Turato G, et al. CD8+ Tlymphocytes in peripheral airways of smokers with chronic obstructive pulmonary disease. Am J Respir Crit Care Med 1998; 157: 822-826.

11 Brightling CE, Bradding P, Symon FA, Holgate ST, Wardlaw AJ, Pavord ID. Mast-cell infiltration of airway smooth muscle in asthma. N Engl J Med 2002; 346: 16991705.

12 Carroll NG, Mutavdzic S, James AL. Distribution and degranulation of airway mast cells in normal and asthmatic subjects. Eur Respir J 2002; 19: 879-885.

13 Amin K, Janson C, Boman G, Venge P. The extracellular deposition of mast cell products is increased in hypertrophic airways smooth muscles in allergic asthma but not in nonallergic asthma. Allergy 2005; 60: 1241-1247.

14 Ammit AJ, Bekir SS, Johnson PR, Hughes JM, Armour CL, Black JL. Mast cell numbers are increased in the smooth muscle of human sensitized isolated bronchi. Am J Respir Crit Care Med 1997; 155: 1123-1129.

15 Koshino T, Teshima S, Fukushima N, et al. Identification of basophils by immunohistochemistry in the airways of post-mortem cases of fatal asthma. Clin Exp Allergy 1993; 23: 919-925.

16 Berger P, Girodet PO, Begueret $\mathrm{H}$, et al. Tryptasestimulated human airway smooth muscle cells induce cytokine synthesis and mast cell chemotaxis. FASEB J 2003; 17: 2139-2141.

17 El Shazly A, Berger P, Girodet PO, et al. Fraktalkine produced by airway smooth muscle cells contributes to mast cell recruitment in asthma. J Immunol 2006; 176: 1860-1868.
18 Begueret $\mathrm{H}$, Berger P, Vernejoux JM, Dubuisson L, Marthan R, Tunon-de-Lara JM. Inflammation of bronchial smooth muscle in allergic asthma. Thorax 2007; 62: 8-15.

19 Baraldo S, Turato G, Badin C, et al. Neutrophilic infiltration within the airway smooth muscle in patients with COPD. Thorax 2004; 59: 308-312.

20 Laitinen LA, Laitinen A, Haahtela T. Airway mucosal inflammation even in patients with newly diagnosed asthma. Am Rev Respir Dis 1993; 147: 697-704.

21 Shahana S, Bjornsson E, Ludviksdottir D, et al. Ultrastructure of bronchial biopsies from patients with allergic and non-allergic asthma. Respir Med 2005; 99: 429-443.

22 Foresi A, Bertorelli G, Pesci A, Chetta A, Olivieri D. Inflammatory markers in bronchoalveolar lavage and in bronchial biopsy in asthma during remission. Chest 1990; 98: 528-535.

23 Pesci A, Foresi A, Bertorelli G, Chetta A, Olivieri D. Histochemical characteristics and degranulation of mast cells in epithelium and lamina propria of bronchial biopsies from asthmatic and normal subjects. Am Rev Respir Dis 1993; 147: 684-689.

24 Gibson PG, Allen CJ, Yang JP, et al. Intraepithelial mast cells in allergic and nonallergic asthma. Assessment using bronchial brushings. Am Rev Respir Dis 1993; 148 80-86.

25 Brightling CE, Symon FA, Birring SS, Bradding P, Wardlaw AJ, Pavord ID. Comparison of airway immunopathology of eosinophilic bronchitis and asthma. Thorax 2003; 58: 528-532.

26 Kaur D, Saunders R, Berger P, et al. Airway smooth muscle and mast cell-derived CC chemokine ligand 19 mediate airway smooth muscle migration in asthma. Am J Respir Crit Care Med 2006; 174: 1179-1188.

27 Ying S, O'Connor B, Ratoff J, et al. Thymic stromal lymphopoietin expression is increased in asthmatic airways and correlates with expression of Th2-attracting chemokines and disease severity. J Immunol 2005; 174: 8183-8190.

28 Djukanovic R, Homeyard S, Gratziou C, et al. The effect of treatment with oral corticosteroids on asthma symptoms and airway inflammation. Am J Respir Crit Care Med 1997; 155: 826-832.

29 Djukanovic R, Wilson JW, Britten KM, et al. Quantitation of mast cells and eosinophils in the bronchial mucosa of symptomatic atopic asthmatics and healthy control subjects using immunohistochemistry. Am Rev Respir Dis 1990; 142: 863-871.

30 Laitinen LA, Laitinen A, Haahtela T. A comparative study of the effects of an inhaled corticosteroid, budesonide, and a $\beta 2$-agonist, terbutaline, on airway inflammation in newly diagnosed asthma: a randomized, double-blind, parallel-group controlled trial. I Allergy Clin Immunol 1992; 90: 32-42.

31 Saetta M, Turato G, Facchini FM, et al. Inflammatory cells in the bronchial glands of smokers with chronic bronchitis. Am J Respir Crit Care Med 1997; 156: 1633-1639.

32 Pesci A, Rossi GA, Bertorelli G, Aufiero A, Zanon P, Olivieri D. Mast cells in the airway lumen and bronchial 
mucosa of patients with chronic bronchitis. Am J Respir Crit Care Med 1994; 149: 1311-1316.

33 Hattotuwa KL, Gizycki MJ, Ansari TW, Jeffery PK, Barnes NC. The effects of inhaled fluticasone on airway inflammation in chronic obstructive pulmonary disease: a double-blind, placebo-controlled biopsy study. Am J Respir Crit Care Med 2002; 165: 1592-1596.

34 Saetta M, Di Stefano A, Maestrelli P, et al. Activated Tlymphocytes and macrophages in bronchial mucosa of subjects with chronic bronchitis. Am Rev Respir Dis 1993; 147: 301-306.

35 Panzner P, Lafitte JJ, Tsicopoulos A, Hamid Q, Tulic MK. Marked up-regulation of T lymphocytes and expression of interleukin-9 in bronchial biopsies from patients with chronic bronchitis with obstruction. Chest 2003; 124: 1909-1915.

36 Turato G, Zuin R, Miniati M, et al. Airway inflammation in severe chronic obstructive pulmonary disease: relationship with lung function and radiologic emphysema. Am J Respir Crit Care Med 2002; 166: 105-110.

37 Chen FH, Samson KT, Miura K, et al. Airway remodeling: a comparison between fatal and nonfatal asthma. J Asthma 2004; 41: 631-638.

38 Carroll NG, Mutavdzic S, James AL. Increased mast cells and neutrophils in submucosal mucous glands and mucus plugging in patients with asthma. Thorax 2002; 57: 677-682.

39 Zhu J, Qiu Y, Valobra M, et al. Plasma cells and IL-4 in chronic bronchitis and chronic obstructive pulmonary disease. Am J Respir Crit Care Med 2007; 175: 1125-1133.

40 Jeffery P, Zhu J. Mucin-producing elements and inflammatory cells. Novartis Found Symp 2002; 248: 51-68.

41 Costello RW, Schofield BH, Kephart GM, Gleich GJ, Jacoby DB, Fryer AD. Localization of eosinophils to airway nerves and effect on neuronal M2 muscarinic receptor function. Am J Physiol 1997; 273: L93-L103.

42 Liesker JJ, Ten Hacken NH, Rutgers SR, ZeinstraSmith M, Postma DS, Timens W. Mast cell numbers in airway smooth muscle and PC20AMP in asthma and COPD. Respir Med 2007; 101: 882-887.

43 Brightling CE, Symon FA, Holgate ST, Wardlaw AJ, Pavord ID, Bradding P. Interleukin- 4 and -13 expression is co-localized to mast cells within the airway smooth muscle in asthma. Clin Exp Allergy 2003; 33: 1711-1716.

44 Slats AM, Janssen K, van Schadewijk A, et al. Bronchial inflammation and airway responses to deep inspiration in asthma and COPD. Am J Respir Crit Care Med 2007; 15: 121-128.

45 Berger P, Laurent F, Begueret H, et al. Structure and function of small airways in smokers: relationship between air trapping at CT and airway inflammation. Radiology 2003; 228: 85-94.

46 Saha S, Neale N, Wardlaw AJ, Pavord ID, Brightling CE. Inflammatory cell infiltration into proximal airway smooth muscle bundles in subjects with and without chronic obstructive pulmonary disease. Thorax 2006; 61: Suppl. II, ii107-ii108.

47 Yang W, Kaur D, Okayama Y, et al. Human lung mast cells adhere to human airway smooth muscle, in part, via tumor suppressor in lung cancer-1. J Immunol 2006; 176: $1238-1243$.
48 Brightling CE, Pavord JD. Eosinophilic bronchitis is an important cause of chronic cough. Am J Respir Crit Care Med 2000; 161: 1765.

49 Brightling CE. Chronic cough due to nonasthmatic eosinophilic bronchitis: ACCP evidence-based clinical practice guidelines. Chest 2006; 129: Suppl. 1, 116S-121S.

50 Berry MA, Hargadon B, McKenna S, et al. Observational study of the natural history of eosinophilic bronchitis. Clin Exp Allergy 2005; 35: 598-601.

51 Balzar S, Chu MD, Wenzel SE. Mast cell phenotypes in large airway smooth muscle and submucosa of normal subjects and asthmatics do not correlate with lung function. Am J Respir Crit Care Med 2005; A348.

52 Brightling CE, Bradding P, Pavord ID, Wardlaw AJ. New insights into the role of the mast cell in asthma. Clin Exp Allergy 2003; 33: 550-556.

53 Saha S, Neale N, Berry M, et al. Interleukin-13+ cells are increased in the airway smooth muscle bundle of asthmatics but not COPD. Am J Respir Crit Care Med 2006; A29.

54 Laporte JC, Moore PE, Baraldo S, et al. Direct effects of interleukin-13 on signaling pathways for physiological responses in cultured human airway smooth muscle cells. Am J Respir Crit Care Med 2001; 164: 141-148.

55 Grunstein MM, Hakonarson H, Leiter J, et al. IL-13dependent autocrine signaling mediates altered responsiveness of IgE-sensitized airway smooth muscle. Am J Physiol Lung Cell Mol Physiol 2002; 282: L520-L528.

56 Johnson PR, Ammit AJ, Carlin SM, Armour CL, Caughey GH, Black JL. Mast cell tryptase potentiates histamine-induced contraction in human sensitized bronchus. Eur Respir J 1997; 10: 38-43.

57 Gray PR, Mitchell HW. Intramural elastase injection increases responsiveness of isolated bronchial segments. Pulm Pharmacol 1996; 9: 239-243.

58 Christensen GC, Lev A, Ryan J, et al. Rabbit trachealis tension responses to receptor-mediated agonists are diminished by elastase. Am J Respir Cell Mol Biol 1992; 6: 498-503.

59 Woodman L, Kaur D, Sutcliffe A, Bradding P, Brightling CE. $\alpha$-Smooth muscle actin expression by human airway smooth muscle cells is upregulated in coculture with mast cells. Thorax 2005; 60: Suppl. 2, ii118.

60 Carroll N, Elliot J, Morton A, James A. The structure of large and small airways in nonfatal and fatal asthma. Am Rev Respir Dis 1993; 147: 405-410.

61 Panettieri RA, Yadvish PA, Kelly AM, Rubinstein NA, Kotlikoff MI. Histamine stimulates proliferation of airway smooth muscle and induces c-fos expression. Am J Physiol 1990; 259: L365-L371.

62 Berger P, Perng DW, Thabrew H, et al. Tryptase and agonists of PAR-2 induce the proliferation of human airway smooth muscle cells. J Appl Physiol 2001; 91: 1372-1379.

63 Espinosa K, Bosse Y, Stankova J, Rola-Pleszczynski M. CysLT1 receptor upregulation by TGF- $\beta$ and IL-13 is associated with bronchial smooth muscle cell proliferation in response to LTD4. J Allergy Clin Immunol 2003; 111: 1032-1040.

64 Huang $\mathrm{CD}$, Chen $\mathrm{HH}$, Wang $\mathrm{CH}$, et al. Human neutrophil-derived elastase induces airway smooth muscle cell proliferation. Life Sci 2004; 74: 2479-2492. 
65 Schmidt M, Sun G, Stacey MA, Mori L, Mattoli S. Identification of circulating fibrocytes as precursors of bronchial myofibroblasts in asthma. J Immunol 2003; 171: 380-389.

66 Lambert RK, Wiggs BR, Kuwano K, Hogg JC, Pare PD. Functional significance of increased airway smooth muscle in asthma and COPD. J Appl Physiol 1993; 74: 2771-2781.

67 Holgate ST, Davies DE, Lackie PM, Wilson SJ, Puddicombe SM, Lordan JL. Epithelial-mesenchymal interactions in the pathogenesis of asthma. J Allergy Clin Immunol 2000; 105: 193-204.

68 Holgate ST, Lackie PM, Howarth $\mathrm{PH}$, et al. Invited lecture: activation of the epithelial mesenchymal trophic unit in the pathogenesis of asthma. Int Arch Allergy Immunol 2001; 124: 253-258.

69 Brewster CE, Howarth PH, Djukanovic R, Wilson J, Holgate ST, Roche WR. Myofibroblasts and subepithelial fibrosis in bronchial asthma. Am J Respir Cell Mol Biol 1990; 3: 507-511.

70 Plante S, Semlali A, Joubert P, et al. Mast cells regulate procollagen I $\left(\alpha_{1}\right)$ production by bronchial fibroblasts derived from subjects with asthma through IL-4/IL-4 $\delta 2$ ratio. J Allergy Clin Immunol 2006; 117: 1321-1327.

71 Richter A, Puddicombe SM, Lordan JL, et al. The contribution of interleukin (IL)-4 and IL-13 to the epithelial-mesenchymal trophic unit in asthma. Am J Respir Cell Mol Biol 2001; 25: 385-391.

72 Berry MA, Parker D, Neale N, et al. Sputum and bronchial submucosal IL-13 expression in asthma and eosinophilic bronchitis. J Allergy Clin Immunol 2004; 114: 1106-1109.

73 Bentley AM, Hamid Q, Robinson DS, et al. Prednisolone treatment in asthma. Reduction in the numbers of eosinophils, $\mathrm{T}$ cells, tryptase-only positive mast cells, and modulation of IL-4, IL-5, and interferon- $\gamma$ cytokine gene expression within the bronchial mucosa. Am J Respir Crit Care Med 1996; 153: 551-556.

74 Dunnill MS, Massarella GR, Anderson JA. A comparison of the quantitative anatomy of the bronchi in normal subjects, in status asthmaticus, in chronic bronchitis, and in emphysema. Thorax 1969; 24: 176-179.

75 Aikawa T, Shimura S, Sasaki H, Ebina M, Takishima T. Marked goblet cell hyperplasia with mucus accumulation in the airways of patients who died of severe acute asthma attack. Chest 1992; 101: 916-921.

76 Aikawa T, Shimura S, Sasaki H, Takishima T, Yaegashi H, Takahashi T. Morphometric analysis of intraluminal mucus in airways in chronic obstructive pulmonary disease. Am Rev Respir Dis 1989; 140: 477-482.

77 Cohn L, Whittaker L, Niu N, Homer RJ. Cytokine regulation of mucus production in a model of allergic asthma. Novartis Found Symp 2002; 248: 201-213.

78 Dabbagh K, Takeyama K, Lee HM, Ueki IF, Lausier JA, Nadel JA. IL-4 induces mucin gene expression and goblet cell metaplasia in vitro and in vivo. J Immunol 1999; 162: 6233-6237.

79 Wang SW, Oh CK, Cho SH, et al. Amphiregulin expression in human mast cells and its effect on the primary human lung fibroblasts. J Allergy Clin Immunol 2005; 115: 287-294.
80 Okumura S, Sagara H, Fukuda T, Saito H, Okayama Y. Fce RI-mediated amphiregulin production by human mast cells increases mucin gene expression in epithelial cells. J Allergy Clin Immunol 2005; 115: 272-279.

81 Shao MX, Nadel JA. Neutrophil elastase induces MUC5AC mucin production in human airway epithelial cells via a cascade involving protein kinase $\mathrm{C}$, reactive oxygen species, and TNF- $\alpha$-converting enzyme. J Immunol 2005; 175: 4009-4016.

82 Voynow JA, Young LR, Wang Y, Horger T, Rose MC, Fischer BM. Neutrophil elastase increases MUC5AC mRNA and protein expression in respiratory epithelial cells. Am J Physiol 1999; 276: L835-L843.

83 Sanmugalingam D, Wardlaw AJ, Bradding P. Adhesion of human lung mast cells to bronchial epithelium: evidence for a novel carbohydrate-mediated mechanism. J Leukoc Biol 2000; 68: 38-46.

84 Columbo M, Horowitz EM, Botana LM, et al. The human recombinant c-kit receptor ligand, rhSCF, induces mediator release from human cutaneous mast cells and enhances IgE-dependent mediator release from both skin mast cells and peripheral blood basophils. J Immunol 1992; 149: 599-608.

85 Cairns JA, Walls AF. Mast cell tryptase is a mitogen for epithelial cells. Stimulation of IL-8 production and intercellular adhesion molecule-1 expression. J Immunol 1996; 156: 275-283.

86 Yang W, Wardlaw AJ, Bradding P. Attenuation of human lung mast cell degranulation by bronchial epithelium. Allergy 2006; 61: 569-575.

87 Sato M, Takizawa H, Kohyama T, et al. Eosinophil adhesion to human bronchial epithelial cells: regulation by cytokines. Int Arch Allergy Immunol 1997; 113: 203-205.

88 Godding V, Stark JM, Sedgwick JB, Busse WW. Adhesion of activated eosinophils to respiratory epithelial cells is enhanced by tumor necrosis factor- $\alpha$ and interleukin- $1 \beta$. Am J Respir Cell Mol Biol 1995; 13: 555-562.

89 Takafuji S, Ohtoshi T, Takizawa H, Tadokoro K, Ito K. Eosinophil degranulation in the presence of bronchial epithelial cells. Effect of cytokines and role of adhesion. I Immunol 1996; 156: 3980-3985.

90 Trautmann A, Schmid-Grendelmeier P, Kruger K, et al. $\mathrm{T}$ cells and eosinophils cooperate in the induction of bronchial epithelial cell apoptosis in asthma. J Allergy Clin Immunol 2002; 109: 329-337.

91 Mattoli S, Miante S, Calabro F, Mezzetti M, Fasoli A, Allegra L. Bronchial epithelial cells exposed to isocyanates potentiate activation and proliferation of T-cells. Am I Physiol 1990; 259: L320-L327.

92 Ordonez C, Ferrando R, Hyde DM, Wong HH, Fahy JV. Epithelial desquamation in asthma: artifact or pathology? Am J Respir Crit Care Med 2000; 162: 2324-2329.

93 Fahy JV. Remodeling of the airway epithelium in asthma. Am J Respir Crit Care Med 2001; 164: S46-S51.

94 Vliagoftis H, Befus AD, Hollenberg MD, Moqbel R. Airway epithelial cells release eosinophil survival-promoting factors (GM-CSF) after stimulation of proteinase-activated receptor 2. J Allergy Clin Immunol 2001; 107: 679-685.

95 Soumelis V, Reche PA, Kanzler H, et al. Human epithelial cells trigger dendritic cell mediated allergic inflammation by producing TSLP. Nat Immunol 2002; 3: 673-680. 
96 de Jong EC, Vieira PL, Kalinski P, et al. Microbial compounds selectively induce Th1 cell-promoting or Th2 cell-promoting dendritic cells in vitro with diverse Th cell-polarizing signals. J Immunol 2002; 168: 1704-1709.

97 Propst SM, Denson R, Rothstein E, Estell K, Schwiebert LM. Proinflammatory and Th2-derived cytokines modulate CD40-mediated expression of inflammatory mediators in airway epithelia: implications for the role of epithelial CD40 in airway inflammation. J Immunol 2000; 165: 2214-2221.

98 Colebatch H, Halmagyi DF. Effect of vagotomy and vagal stimulation on lung mechanics and circulation. J Appl Physiol 1963; 18: 881-887.

99 Baker B, Peatfield AC, Richardson PS. Nervous control of mucin secretion into human bronchi. J Physiol 1985; 365: 297-305.

100 Laitinen LA, Laitinen MV, Widdicombe JG. Parasympathetic nervous control of tracheal vascular resistance in the dog. J Physiol 1987; 385: 135-146.

101 Whicker SD, Armour CL, Black JL. Responsiveness of bronchial smooth muscle from asthmatic patients to relaxant and contractile agonists. Pulm Pharmacol 1988; 1: 25-31.

102 Haddad EB, Mak JC, Belvisi MG, Nishikawa M, Rousell J, Barnes PJ. Muscarinic and $\beta$-adrenergic receptor expression in peripheral lung from normal and asthmatic patients. Am J Physiol 1996; 270: L947-L953.

103 Durcan N, Costello RW, McLean WG, et al. Eosinophilmediated cholinergic nerve remodeling. Am J Respir Cell Mol Biol 2006; 34: 775-786.

104 Birring SS, Parker D, Brightling CE, Bradding P, Wardlaw AJ, Pavord ID. Induced sputum inflammatory mediator concentrations in chronic cough. Am J Respir Crit Care Med 2004; 169: 15-19.

105 Brightling CE, Ward R, Woltmann G, et al. Induced sputum inflammatory mediator concentrations in eosinophilic bronchitis and asthma. Am J Respir Crit Care Med 2000; 162: 878-882.

106 Gibson PG. Cough is an airway itch? Am J Respir Crit Care Med 2004; 169: 1-2.

107 Yosipovitch G, Greaves MW, Schmelz M. Itch. Lancet 2003; 361: 690-694.

108 Hashimoto M, Tanaka H, Abe S. Quantitative analysis of bronchial wall vascularity in the medium and small airways of patients with asthma and COPD. Chest 2005; 127: 965-972.

109 Feltis BN, Wignarajah D, Zheng L, et al. Increased vascular endothelial growth factor and receptors: relationship to angiogenesis in asthma. Am J Respir Crit Care Med 2006; 173: 1201-1207.

110 Chetta A, Zanini A, Foresi A, et al. Vascular endothelial growth factor up-regulation and bronchial wall remodelling in asthma. Clin Exp Allergy 2005; 35: 1437-1442.

111 Chetta A, Zanini A, Foresi A, et al. Vascular component of airway remodeling in asthma is reduced by high dose of fluticasone. Am J Respir Crit Care Med 2003; 167: 751-757.

112 Kanazawa H, Nomura S, Yoshikawa J. Role of microvascular permeability on physiologic differences in asthma and eosinophilic bronchitis. Am J Respir Crit Care Med 2004; 169: 1125-1130.
113 Siddiqui S, Brightling CE. Differences in airway wall remodelling in asthma and EB. Thorax 2006; 61: 547.

114 Siddiqui S, Sutcliffe A, Shikotra A, et al. Vascular remodeling is a feature of asthma and nonasthmatic eosinophilic bronchitis. J Allergy Clin Immunol 2007; [Epub ahead of print PMID: 17610643].

115 Asai K, Kanazawa H, Kamoi H, Shiraishi S, Hirata K, Yoshikawa J. Increased levels of vascular endothelial growth factor in induced sputum in asthmatic patients. Clin Exp Allergy 2003; 33: 595-599.

116 Hoshino M, Takahashi M, Aoike N. Expression of vascular endothelial growth factor, basic fibroblast growth factor, and angiogenin immunoreactivity in asthmatic airways and its relationship to angiogenesis. J Allergy Clin Immunol 2001; 107: 295-301.

117 Wardlaw AJ. Molecular basis for selective eosinophil trafficking in asthma: a multistep paradigm. J Allergy Clin Immunol 1999; 104: 917-926.

118 Foster PS, Hogan SP, Ramsay AJ, Matthaei KI, Young IG. Interleukin 5 deficiency abolishes eosinophilia, airways hyperreactivity, and lung damage in a mouse asthma model. J Exp Med 1996; 183: 195-201.

119 Dent LA, Strath M, Mellor AL, Sanderson CJ. Eosinophilia in transgenic mice expressing interleukin 5. J Exp Med 1990; 172: 1425-1431.

120 Sehmi R, Wardlaw AJ, Cromwell O, Kurihara K, Waltmann P, Kay AB. Interleukin-5 selectively enhances the chemotactic response of eosinophils obtained from normal but not eosinophilic subjects. Blood 1992; 79: 2952-2959.

121 Gonzalo JA, Lloyd CM, Wen D, et al. The coordinated action of CC chemokines in the lung orchestrates allergic inflammation and airway hyperresponsiveness. J Exp Med 1998; 188: 157-167.

122 Woltmann G, McNulty CA, Dewson G, Symon FA, Wardlaw AJ. Interleukin-13 induces PSGL-1/P-selectindependent adhesion of eosinophils, but not neutrophils, to human umbilical vein endothelial cells under flow. Blood 2000; 95: 3146-3152.

123 Symon FA, Lawrence MB, Williamson ML, Walsh GM, Watson SR, Wardlaw AJ. Functional and structural characterization of the eosinophil P-selectin ligand. J Immunol 1996; 157: 1711-1719.

124 Edwards BS, Curry MS, Tsuji H, Brown D, Larson RS, Sklar LA. Expression of P-selectin at low site density promotes selective attachment of eosinophils over neutrophils. J Immunol 2000; 165: 404-410.

125 Erle DJ, Briskin MJ, Butcher EC, Garcia-Pardo A, Lazarovits AI, Tidswell M. Expression and function of the MAdCAM-1 receptor, integrin $\alpha 4 \beta 7$, on human leukocytes. J Immunol 1994; 153: 517-528.

126 Walsh GM, Symon FA, Lazarovils AL, Wardlaw AJ. Integrin $\alpha 4 \quad \beta 7$ mediates human eosinophil interaction with MAdCAM-1, VCAM-1 and fibronectin. Immunology 1996; 89: 112-119.

127 Bochner BS, Luscinskas FW, Gimbrone MA Jr, et al. Adhesion of human basophils, eosinophils, and neutrophils to interleukin 1-activated human vascular endothelial cells: contributions of endothelial cell adhesion molecules. J Exp Med 1991; 173: 1553-1557. 
128 DiScipio RG, Daffern PJ, Jagels MA, Broide DH, Sriramarao P. A comparison of C3a and C5a-mediated stable adhesion of rolling eosinophils in postcapillary venules and transendothelial migration in vitro and in vivo. I Immunol 1999; 162: 1127-1136.

129 Rothenberg ME, MacLean JA, Pearlman E, Luster AD, Leder P. Targeted disruption of the chemokine eotaxin partially reduces antigen-induced tissue eosinophilia. J Exp Med 1997; 185: 785-790.

130 Ying S, Meng Q, Zeibecoglou K, et al. Eosinophil chemotactic chemokines (eotaxin, eotaxin-2, RANTES, monocyte chemoattractant protein-3 (MCP-3), and MCP4 ), and C-C chemokine receptor 3 expression in bronchial biopsies from atopic and nonatopic (intrinsic) asthmatics. J Immunol 1999; 163: 6321-6329.

131 Yamaguchi Y, Hayashi Y, Sugama Y, et al. Highly purified murine interleukin 5 (IL-5) stimulates eosinophil function and prolongs in vitro survival. IL-5 as an eosinophil chemotactic factor. J Exp Med 1988; 167: 1737-1742.

132 Kankaanranta H, Lindsay MA, Giembycz MA, Zhang X, Moilanen E, Barnes PJ. Delayed eosinophil apoptosis in asthma. J Allergy Clin Immunol 2000; 106: 77-83.

133 Knox AJ, Pang L, Johnson S, Hamad A. Airway smooth muscle function in asthma. Clin Exp Allergy 2000; 30: 606-614.

134 Oltmanns U, Chung KF, Walters M, John M, Mitchell JA. Cigarette smoke induces IL- 8 , but inhibits eotaxin and RANTES release from airway smooth muscle. Respir Res 2005; 6: 74.

135 Hardaker EL, Bacon AM, Carlson K, et al. Regulation of TNF- $\alpha$ - and IFN- $\gamma$-induced CXCL10 expression: participation of the airway smooth muscle in the pulmonary inflammatory response in chronic obstructive pulmonary disease. FASEB J 2004; 18: 191-193.

136 Hirst SJ, Hallsworth MP, Peng Q, Lee TH. Selective induction of eotaxin release by interleukin-13 or interleukin-4 in human airway smooth muscle cells is synergistic with interleukin-1 $\beta$ and is mediated by the interleukin- 4 receptor $\alpha$-chain. Am J Respir Crit Care Med 2002; 165: 1161-1171.

137 Brightling CE, Kaur D, Berger P, Morgan AJ, Wardlaw AJ, Bradding P. Differential expression of CCR3 and CXCR3 by human lung and bone marrow-derived mast cells: implications for tissue mast cell migration. I Leuk Biol 2005; 77: 759-766.

138 Sutcliffe A, Kaur D, Page S, et al. Mast cell migration to Th2 stimulated airway smooth muscle from asthmatics. Thorax 2006; 61: 657-662.

139 John M, Au BT, Jose PJ, et al. Expression and release of interleukin- 8 by human airway smooth muscle cells: inhibition by Th-2 cytokines and corticosteroids. Am J Respir Cell Mol Biol 1998; 18: 84-90.

140 Brightling CE, Ammit AJ, Kaur D, et al. The CXCL10/ CXCR3 axis mediates human lung mast cell migration to asthmatic airway smooth muscle. Am J Respir Crit Care Med 2005; 171: 1103-1108.

141 Morris GE, Parker LC, Ward JR, et al. Cooperative molecular and cellular networks regulate Toll-like receptor-dependent inflammatory responses. FASEB J 2006; 20: 2153-2155.
142 Pang L, Nie M, Corbett L, Sutcliffe A, Knox AJ. Mast cell $\beta$-tryptase selectively cleaves eotaxin and RANTES and abrogates their eosinophil chemotactic activities. J Immunol 2006; 176: 3788-3795.

143 Lazaar AL, Plotnick MI, Kucich U, et al. Mast cell chymase modifies cell-matrix interactions and inhibits mitogen-induced proliferation of human airway smooth muscle cells. J Immunol 2002; 169: 1014-1020.

144 Message SD, Johnston SL. Host defense function of the airway epithelium in health and disease: clinical background. J Leukoc Biol 2004; 75: 5-17.

145 Holgate ST, Lackie PM, Davies DE, Roche WR, Walls AF. The bronchial epithelium as a key regulator of airway inflammation and remodelling in asthma. Clin Exp Allergy 1999; 29: Suppl. 2, 90-95.

146 Woodman L, Kaur D, Morgan A, et al. Chemokine concentrations in induced sputum and bronchoalveolar lavage in eosinophilic bronchitis, asthma, and normal controls. Thorax 2004; 59: 90.

147 Keatings VM, Collins PD, Scott DM, Barnes PJ. Differences in interleukin- 8 and tumor necrosis factor- $\alpha$ in induced sputum from patients with chronic obstructive pulmonary disease or asthma. Am J Respir Crit Care Med 1996; 153: 530-534.

148 Gompertz S, O’Brien C, Bayley DL, Hill SL, Stockley RA. Changes in bronchial inflammation during acute exacerbations of chronic bronchitis. Eur Respir J 2001; 17: 1112-1119.

149 Gibson PG, Simpson JL, Saltos N. Heterogeneity of airway inflammation in persistent asthma: evidence of neutrophilic inflammation and increased sputum interleukin-8. Chest 2001; 119: 1329-1336.

150 Chalmers GW, MacLeod KJ, Thomson L, Little SA, McSharry C, Thomson NC. Smoking and airway inflammation in patients with mild asthma. Chest 2001; 120: 1917-1922.

151 Inoue $\mathrm{H}$, Massion PP, Ueki IF, et al. Pseudomonas stimulates interleukin-8 mRNA expression selectively in airway epithelium, in gland ducts, and in recruited neutrophils. Am J Respir Cell Mol Biol 1994; 11: 651-663.

152 Fryer AD, Stein LH, Nie Z, et al. Neuronal eotaxin and the effects of CCR3 antagonist on airway hyperreactivity and M2 receptor dysfunction. J Clin Invest 2006; 116: 228-236.

153 Ramos-Barbon D, Presley JF, Hamid QA, Fixman ED, Martin JG. Antigen-specific CD4+ T cells drive airway smooth muscle remodeling in experimental asthma. $J$ Clin Invest 2005; 115: 1580-1589.

154 Huang JH, Cardenas-Navia LI, Caldwell CC, et al. Requirements for $\mathrm{T}$ lymphocyte migration in explanted lymph nodes. J Immunol 2007; 178: 7747-7755.

155 Innes AL, Woodruff PG, Ferrando RE, et al. Epithelial mucin stores are increased in the large airways of smokers with airflow obstruction. Chest 2006; 130: 1102-1108.

156 Hays SR, Ferrando RE, Carter R, Wong $\mathrm{HH}$, Woodruff PG. Structural changes to airway smooth muscle in cystic fibrosis. Thorax 2005; 60: 226-228.

157 Ferrando RE, Nyengaard JR, Hays SR, Fahy JV, Woodruff PG. Applying stereology to measure thickness of the basement membrane zone in bronchial biopsy specimens. J Allergy Clin Immunol 2003; 112: 1243-1245.

158 Woodruff PG, Dolganov GM, Ferrando RE, et al. Hyperplasia of smooth muscle in mild to moderate 
asthma without changes in cell size or gene expression. Am J Respir Crit Care Med 2004; 169: 1001-1006.

159 Hasegawa M, Nasuhara Y, Onodera Y, et al. Airflow limitation and airway dimensions in chronic obstructive pulmonary disease. Am J Respir Crit Care Med 2006; 173: 1309-1315.

160 Niimi A, Matsumoto H, Takemura M, Ueda T, Nakano Y, Mishima M. Clinical assessment of airway remodeling in asthma: utility of computed tomography. Clin Rev Allergy Immunol 2004; 27: 45-58.

161 Vignola AM, Paganin F, Capieu L, et al. Airway remodelling assessed by sputum and high-resolution computed tomography in asthma and COPD. Eur Respir J 2004; 24: 910-917.

162 Martinez TM, Llapur CJ, Williams TH, et al. Highresolution computed tomography imaging of airway disease in infants with cystic fibrosis. Am J Respir Crit Care Med 2005; 172: 1133-1138.

163 Gizycki MJ, Hattotuwa KL, Barnes N, Jeffery PK. Effects of fluticasone propionate on inflammatory cells in COPD: an ultrastructural examination of endobronchial biopsy tissue. Thorax 2002; 57: 799-803.

164 Barnes NC, Qiu YS, Pavord ID, et al. Antiinflammatory effects of salmeterol/fluticasone propionate in chronic obstructive lung disease. Am J Respir Crit Care Med 2006; 173: 736-743.

165 Faul JL, Demers EA, Burke CM, Poulter LW. Alterations in airway inflammation and lung function during corticosteroid therapy for atopic asthma. Chest 2002; 121: 1414-1420.

166 Faul JL, Leonard CT, Burke CM, Tormey VJ, Poulter LW. Fluticasone propionate induced alterations to lung function and the immunopathology of asthma over time. Thorax 1998; 53: 753-761.

167 O'Sullivan S, Cormican L, Murphy M, Poulter LW, Burke CM. Effects of varying doses of fluticasone propionate on the physiology and bronchial wall immunopathology in mild-to-moderate asthma. Chest 2002; 122: 1966-1972.

168 O'Sullivan S, Cormican L, Burke CM, Poulter LW. Fluticasone induces $\mathrm{T}$ cell apoptosis in the bronchial wall of mild to moderate asthmatics. Thorax 2004; 59: 657-661.

169 Bentley AM, Hamid Q, Robinson DS, et al. Prednisolone treatment in asthma. Reduction in the numbers of eosinophils, $\mathrm{T}$ cells, tryptase-only positive mast cells, and modulation of IL-4, IL-5, and interferon- $\gamma$ cytokine gene expression within the bronchial mucosa. Am J Respir Crit Care Med 1996; 153: 551-556.

170 Trigg CJ, Manolitsas ND, Wang J, et al. Placebo-controlled immunopathologic study of four months of inhaled corticosteroids in asthma. Am J Respir Crit Care Med 1994; 150: 17-22.

171 Djukanovic R, Wilson JW, Britten KM, et al. Effect of an inhaled corticosteroid on airway inflammation and symptoms in asthma. Am Rev Respir Dis 1992; 145: 669-674.

172 Djukanovic R, Wilson SJ, Kraft M, et al. Effects of treatment with anti-immunoglobulin $\mathrm{E}$ antibody omalizumab on airway inflammation in allergic asthma. Am J Respir Crit Care Med 2004; 170: 583-593.

173 Gamble E, Grootendorst DC, Brightling CE, et al. Antiinflammatory effects of the phosphodiesterase- 4 inhibitor cilomilast (Ariflo) in chronic obstructive pulmonary disease. Am J Respir Crit Care Med 2003; 168: 976-982.

174 O'Byrne PM. Cytokines or their antagonists for the treatment of asthma. Chest 2006; 130: 244-250.

175 Flood-Page PT, Menzies-Gow AN, Kay AB, Robinson DS. Eosinophil's role remains uncertain as anti-interleukin-5 only partially depletes numbers in asthmatic airway. Am J Respir Crit Care Med 2003; 167: 199-204.

176 Mahler DA, Huang S, Tabrizi M, Bell GM. Efficacy and safety of a monoclonal antibody recognizing interleukin8 in COPD: a pilot study. Chest 2004; 126: 926-934.

177 Cruse G, Duffy SM, Brightling CE, Bradding P. Functional KCa3.1 K+ channels are required for human lung mast cell migration. Thorax 2006; 61: 880-885. 